This item was submitted to Loughborough's Research Repository by the author.

Items in Figshare are protected by copyright, with all rights reserved, unless otherwise indicated.

\title{
Global city-region governance, ten years on
}

PLEASE CITE THE PUBLISHED VERSION

http://www.e-elgar.co.uk/search_results.lasso?series_title=Elgar original reference\&series_search=Yes

PUBLISHER

(C) Edward Elgar Publishing

VERSION

AM (Accepted Manuscript)

LICENCE

CC BY-NC-ND 4.0

REPOSITORY RECORD

Harrison, John. 2019. "Global City-region Governance, Ten Years on”. figshare.

https://hdl.handle.net/2134/6634. 
This item was submitted to Loughborough's Institutional Repository (https://dspace.lboro.ac.uk/) by the author and is made available under the following Creative Commons Licence conditions.

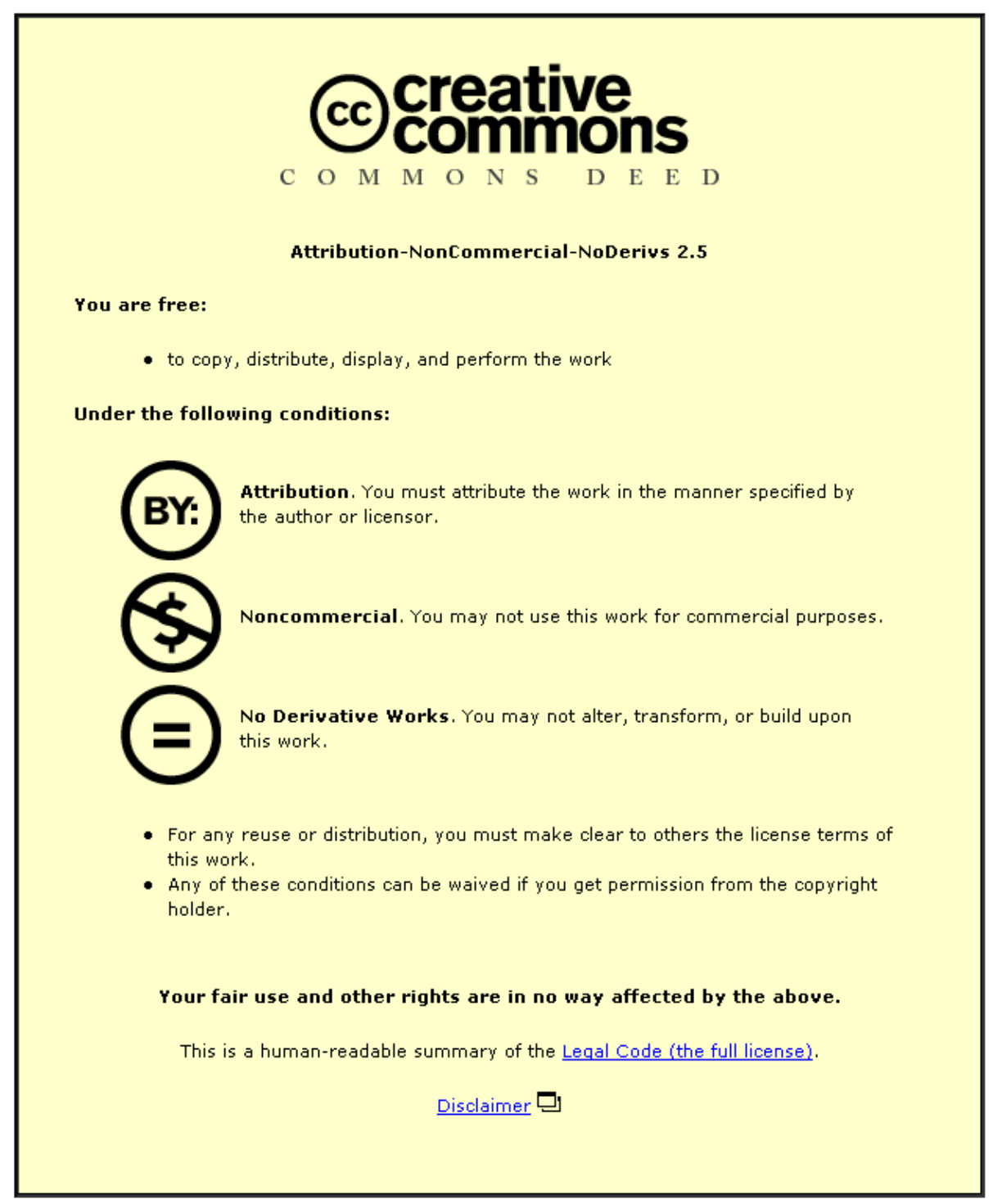

For the full text of this licence, please go to: http://creativecommons.org/licenses/by-nc-nd/2.5/ 
GLOBAL CITY-REGION GOVERNANCE, TEN YEARS ON

\author{
John Harrison \\ Department of Geography \\ Loughborough University \\ Loughborough \\ Leicestershire \\ United Kingdom \\ LE11 3TU \\ $+44(0) 1509228198$ \\ j.harrison4@lboro.ac.uk
}

In: Taylor P, Derudder B, Hoyler M \& Witlox F (eds.) (2011) International Handbook of Globalization and World Cities. Elgar: London 


\section{GLOBAL CITY-REGION GOVERNANCE, TEN YEARS ON}

\section{Introduction}

It is exactly ten years since Allen Scott's (2001a) edited collection Global City-Regions Trends, Theory, Policy became the antecedent to a resurgent interest among academic and policy communities in the 'city-region' concept. In the book, Scott, along with fellow contributors Saskia Sassen, Peter Hall, John Friedman, Kenichi Ohmae, Michael Porter, John Agnew, Ed Soja and Michael Storper amongst others, conceptually map and empirically demonstrate how at the beginning of the twenty-first century there is a new and critically important kind of geography and institutional phenomenon on the world stage - the global city-region. Furthermore, they use the concept of the global city-region to set out how processes of global economic integration and accelerated urbanisation - the defining features of globalization - are serving to make traditional planning and policy strategies 'increasingly inadequate'. It is apt then that ten years on we should revisit, first, the concept of the global city-region, and second, the governance of these pivotal social formations in this International Handbook of Globalization and World Cities.

What follows constitutes a necessarily brief synopsis of some of the key arguments on the governance of global city-regions. This focus on governance is particularly important given that while global city-regions have been identified as a new scale of urban organisation, the pace of change - particularly in relation to their unrelenting expansion in size, scale, and number - means these pivotal social formations are often reliant upon outdated and inadequate institutional structures, frameworks and supports. This was noted by Scott ten years ago, prompting him to raise the important question: What main governance tasks do global city-regions face as they seek to preserve and enhance their 
wealth and well-being? (Scott et al., 2001, 12) A decade on we can argue that this question remains as important as ever - maybe even more so? For despite having more information and more knowledge of what mechanisms are in place, and how different policymakers, strategists and jurisdictions are attempting to construct new city-regional governance arrangements, by the very nature of academic inquiry this has raised as many new questions as it has provided answers.

\section{The what, where, when and how of global city-regions and their governance}

Against the backdrop of accounts heralding the transition to a 'borderless world', the cityregion concept has been rejuvenated as part of a wider 'new regionalist' literature documenting how in globalization place-based and site-specific scales of intervention can both anchor and nurture nodes of dense economic, social and political activity. By focusing on heterodox and endogenous ways of doing economic development alongside supply-side innovation strategies, it is argued that actors can capitalise on this increasingly localised agglomeration and intense clustering of socioeconomic activity. For the most part, this has helped cities and regions prosper in globalization. Yet this was not always the case.

In the early stages of globalization, the prospects for cities looked bleak. Under threat globally from increased foreign competition, capital mobility and labour migration, and undermined locally by labour-management disputes and stagflation, cities that were once the epicentre of Fordist mass accumulation were now on the verge of bankruptcy. A serious drag on national economies, the consensus from the mid-1970s through the 1980s and on into the early-1990s was that advances in technology and communication were 
inducing an era of global deconcentration. The prospect of a diminishing role for cities has, however, been dispelled in recent years by an increased recognition that although new technologies have indeed extended our capacity to interact across space, the propensity of economic activity to coalesce in dense clusters/agglomerations is being demonstrated by a distinct group of cities, i.e. metropolitan clusters of socioeconomic activity, forging ahead as important staging/command posts in an increasingly globalized world economy.

A measure of the degree to which global economic integration and accelerated urbanisation have gone hand-in-hand is that today, for the first time, more than $50 \%$ of the world's population live in cities (UNFPA, 2007). Spatially, this rapid urbanisation sees the functional economies of large cities (the so-called 'economic footprint') extend beyond traditional boundaries to capture physically separate but functionally networked cities and towns in the surrounding (regional) hinterland - to give three pertinent examples, the city population of Tokyo is 12.8 million but the metropolitan population is 31.7 million, for New York City it is 8.3 and 29.9 million and London 7.6 and 21 million respectively'. From this we can clearly see how despite a resurgence of cities in globalization, the city as traditionally conceived is becoming an increasingly outdated entity.

For many, this new spatiality is best captured by the concept of the city-region. At its most basic, a city-region comprises two distinct but interrelated elements: first, the city, which possesses some specified set of functions or economic activities; and second, a surrounding territory which is exclusive to that city (Parr, 2005). However, this definition can be traced back through most of the twentieth century to Christaller's (1933) central-place theory, and while useful for describing the spatiality of these emerging social formations, it cannot help uncover, let alone explain, the processes by which city-regions are actively 
produced in contemporary globalization. It is here, at the conceptual level, that attention has been directed toward so-called 'global city-regions' - which extending the logic that sees global cities defined by their external linkages are defined by their corresponding internal linkages (Hall, 2001). Presented in this way, global city-regions are showcased as a new scale of urban organisation: one that is simultaneously networked externally on a global scale, and internally is expanding to cover areas in excess of thousands of square kilometres - in some cases extending across national boundaries (e.g. Copenhagen-Malmo, San Diego-Tijuana, Singapore-Johor-Batam). According to Scott and others then, global cityregions amount to a new phase in capitalist territorial development. As places where globalization crystallises out on the ground, global city-regions are seen to have a 'deepening role' in the economy, while socially, culturally and politically they are extolled as “increasingly central to modern life" (Scott et al., 2001, p. 11).

Following on from this, and perhaps not surprisingly, this rhetoric captured the imagination of academic and policy communities alike at the beginning of the twenty-first century. At one level, policymakers have sought to accelerate their city's path to economic competitiveness in and through strategies designed to construct flexible and responsive frameworks of city-regional governance. The result of this is how, today, the task of devising city-regional policies is firmly established as an officially institutionalised task not only across North America and Western Europe, but large parts of Pacific Asia and Latin America also. At another level, the enthusiasm of policymakers the world over to adopt city-regional strategies has seen the notion of a new city-regionalism in economic development and territorial representation become self perpetuating. To borrow Lovering's (1999) terminology, the policy tail can once more be seen wagging the analytical dog, with the 
construction of tiers of city-regional governance being used as further evidence of cityregions acting as autonomous political and economic spaces, elevating city-regionalism to a position of orthodoxy, and fuelling further rounds of policy intervention (Harrison, 2007).

\section{Global city-region governance: some continuing and emerging challenges}

The past ten years have brought into sharp focus a number of continuing and emerging challenges for academics and policymakers when considering the major governance tasks posed by city-regionalism more generally, and by global city-region development in particular. Albeit a partial and inevitably personal take on this, this section identifies three major challenges which, when taken together, outline a research agenda for future inquiry into global city-region governance. The first of these centres on how we define, delimit and designate city-regions.

(i) City-region: object of mystery

In his chapter of Global City-Regions, Peter Hall (2001) focuses his effort on defining, first, what do we mean by a 'global city', and second, what do we mean by a 'global city-region'? Perhaps not surprising given the rich tradition of work developing Sassen's concept of the global city during the 1990s, Hall dedicates 14 pages to this task, but just 2 pages to defining what we mean by a 'global city-region'. Why is this important you might ask? Well ten years on we still do not have the answer. What we have is more definitions, but no commonly accepted one. Take the following examples. For Allen Scott (2001b, p.814), city-regions constitute "dense polarised masses of capital, labour, and social life that are bound up in 
intricate ways in intensifying and far-flung extra-national relationships. As such, they represent an outgrowth of large metropolitan areas - or contiguous sets of metropolitan areas - together with surrounding hinterlands of variable extent which may themselves be sites of scattered urban settlements". In contrast, Mark Tewdwr-Jones and Donald McNeill (2000, p. 131) define the city-region as "a strategic and political level of administration and policy-making, extending beyond the administrative boundaries of a single urban local government authorities to include urban and/or semi-urban hinterlands". And as for how this translates into policymaking, to take the UK government as an example, a city-region is "a functionally inter-related geographical area comprising a central, or core city, as part of a network of urban centres and rural hinterlands. A little bit like the hub (city) and spokes (surrounding urban/rural areas) on a bicycle wheel" (Office of the Deputy Prime Minister, 2005 no pagination).

What we have in all three definitions is the 'reach' or 'footprint' of the city emerging as the key determinant of a city-region, but very different interpretations of how this manifests itself conceptually, but also spatially. So where is the connection to governance I hear you ask? It is worth remembering, as Nigel Thrift (2002, p.205) reminded us nearly a decade ago, that "to govern it is necessary to render the visible space over which government is to be exercised. And this is not simply a matter of looking: space has to be represented, marked out". In other words, the important question that arises is how to render an analytical concept, the global city-region, into a visible space over which government can be exercised. All of which suggests that, at one level, we still face the most fundamental challenge - how to define, delimit and designate city-regions. But at another level, it puts into sharp focus the need to examine how city-regions are being constructed 
politically. For the major issue in city-regional governance today is not how and whether to draw lines around city-regions, but to examine the process through which they are (re)produced (Hudson, 2007).

\section{(ii) Making city-regions visible: a question of politics and economics}

Like the global city, the global city-region is used principally as an analytical concept. As such it does not translate easily into a well defined political jurisdiction with clear territorial boundaries over which political control can be exacted. But it has also seen discourses pertaining to a new city-regionalism constructed around a narrow set of empirical and theoretical issues relating to exchange, interspatial competition and globalization - the 'new economics of city-regions'. Defined in economic terms (travel to work areas, functional economic ties, labour market geographies), all too often what has been missing from city-regional accounts over the past decade is how city-regions are constructed politically, and more specifically, the process by which they are rendered visible spaces. What has resulted from this is a tendency for those promoting the city-region concept to reify the city-region as an agent of wealth creation and redistribution. In response to this, Andrew Jonas and Kevin Ward have argued that having overlooked how city-regions are constructed politically, there is now heightened intellectual urgency around the need to conceptualise the emergence of city-regions as the "product of a particular set of economic, cultural, environmental and political projects, each with their own logics ... to discover for which interests city-regions are necessary and for whom this new territoriality is merely contingent" (2007, p. 176). In particular, they outline how there is need for a "new politics of city-regionalism' centred on important, yet un(der)-represented aspects of city- 
regional theory: a politics of governance and state reterritorialisation; the role of democracy and citizenship in city-region politics; and, tensions around social reproduction and sustainability across city-regions. Not surprisingly this too sparked a flurry of research, this time aimed at illuminating the new politics of city-regionalism. However, while interventions in this area have been doing much to advance debates on how city-regions are constructed politically in recent years, work examining how city-regions are rendered visible spaces has appeared somewhat pre-occupied with their increased visibility in political discourse - often being framed as part of a wider neoliberal agenda. What has been missing is due consideration of the struggle to spatially define, delimit and designate city-regions, with city-regions all too often scripted unreflectively and with little regard for how they have been historically constructed, culturally contested and politically charged (Harrison, 2010).

\section{(iii) The limitation of city-region imitation}

An officially institutionalised task throughout most parts of the world, the task of building city-regional governance is underpinned not only by a strong theoretical rationale but a strong policy rationale. Indeed, while acknowledging that each has its own localised agenda, there are four commonly accepted elements to this policy rationale. First, and despite what can best be described as inconclusive evidence of whether devolution brings about an economic or democratic dividend, there continues to be a recognition globally that devolution of power, resource and authority to the most appropriate level is a desired outcome. In other words, as the in vogue spatial scale the city-region is identified as 'the most appropriate level' and is the main benefactor from this continuing global trend toward devolution. Second, the shift from spatial Keynesianism and policies of redistribution toward 
neoliberal workfare has offered little or no indication of narrowing regional disparities and/or tackling uneven development. With over half the world's population now living in cities, the city is increasingly seen to be an important site of struggle and strategy around the connection between economic growth and quality of life. Moreover, for many proponents of city-regions, collective provision, redistribution, and the narrowing of inequality is something which is actively talked up and championed (Jonas and Ward, 2007). Third, studies of governance suggest that the success of leading cities like New York and Tokyo is underpinned by a history of strong political integration resulting from strong metropolitan government. And finally, fourth, there is general recognition that the best performing cities are those where local government boundaries are most closely matched to the functional geography of the local economy (Cheshire and Magrini, 2009).

With many cities finding themselves under-bounded due to rapid urbanization in the past twenty years, city authorities are increasingly seen as too small, regions too large, and city-regions ideal for effective governance. Alongside and somewhat related to this, political praxis has been dominated by a belief in four normatively charged policy assumptions: that, first, a necessary link exists between economic competitiveness and the city-region scale; second, a necessary link also exists between city-regions and increased social participation, accountability and stakeholder democracy; third, all city-regions can benefit and accelerate their economic growth and raise competitiveness; and fourth, that both points one and two can be secured by establishing city-regional institutions, frameworks and supports. Presenting a multi-sided argument for establishing city-regional governance, it is not surprising how policymakers worldwide have found themselves captivated by the strong theoretical and policy rationale for city-regions. Indeed, the success enjoyed by certain city- 
regions has led policymakers in less prosperous cities and regions to cast increasingly envious eyes toward these growth economies, and enticed them to seek greater engagement with these assumptions through state policies aimed at increasing institutional capacity through an empowered city-regional tier of governance. But having said that, the onset of globalization and the emergence of a strong institutionalist literature - highlighting the importance of hard (organisations, agencies) and soft institutions (trust, loyalty, social capital) to local and regional development - has led to much critical thought being given over to the potential dangers of fast policy transfer and policy mobility. To illustrate this, I want to use the remainder of this section to focus on the case of England to highlight some of the difficulties faced by policymakers as they endeavour to copy the success of leading city-regions by imitating their governance arrangements.

At present there are no less than five clearly defined models of city-region governance in England, each of which has appeared in the past decade, in light of the orthodoxy surrounding city-regions. The first, and most obviously recognisable, are the new city-regional governance structures for London. When Scotland, Wales, Northern Ireland and the eight English regions were being afforded new regional institutions as part of the UK Government's programme of Devolution and Constitutional Change (1997-1999), London, as the only true global city-region was afforded new city-regional governance arrangements centred on the new Greater London Authority (GLA), consisting of a directly-elected Mayor of London and an elected twenty-five member London Assembly. Formally established on 3 March 2000, the GLA is responsible for the strategic administration of London's 32 boroughs and has responsibility primarily for transport, housing, policing, fire and rescue, tackling climate change, health and culture, waste, development and strategic planning. This is then 
delivered through four functional bodies - Transport for London, London Development Agency, the Metropolitan Police Authority and London Fire and Emergency Planning Authority. However, while London has the greatest powers and most closely maps onto Scott's concept of the global city-region, it is noteworthy how even here the institutions of city-regional governance only have jurisdiction over Greater London. Noteworthy is how the boundary of Greater London has remained fixed since 1963, and thus the new governance arrangements only have jurisdiction over an area of $1579 \mathrm{~km}^{2}$ and a population of 7.6 million. Thus when it comes to governance, London's current 'city-region' frameworks are working to boundaries established for the GLAs predecessor, the Greater London Council (established in 1963 and abolished by Margaret Thatcher in 1986), not the global city-region and its population of 21 million that Scott identifies.

In contrast, the four remaining models of city-region governance have emerged as much in locally-rooted responses to London's status as a leading global city-region as they have the global policy orthodoxy surrounding city-regions. Moreover, they bear even less resemblance to the concept of the global city-region. For example, the second model of cityregion governance centres on the Northern Way Growth Strategy, established in 2004 as the UK Government's response to widespread criticism that they were prioritising growth in and around London, and thereby increasing regional disparities between the London cityregion and the rest of the UK. Centred on eight interacting but hierarchically differentiated city-regions, the Northern Way had ambitious aims: to maximise the growth potential of city-regions to drive forward the economy in the North of England, act as a northern counterweight to the economy of London and the south east, and cut the $£ 30$ billion north/south productivity gap. However, while on the surface indicative of the new city- 
regionalism in action, the dovetailing of the Northern Way to the city-region agenda came about more by coincidence than grand design. Initially designed around two growth corridors, the Northern Way was actually formulated to be part of England's post-1997 regional policy. Indeed, it was only after England's regional policy collapsed in November 2004 that the Northern Way was repackaged and branded as a city-region initiative, but even so, there is still clear evidence of its regional ancestry (Harrison, 2010).

Following on from this, the third model of city-region governance centres on City Development Companies (CDCs). First announced in 2006, CDCs are city or city-region wide economic development companies formed to drive economic growth. The premise for CDCs is that international evidence from inter alia Toronto, Baltimore, Greater Washington and Stuttgart shows that economic transformation of a city or city-region requires an arm's length organisation, distanced from local and central government. However, the extent to which CDCs are "giving added impetus to the development of city-regions" remains unproven (DCLG, 2008, p.11). This is because, at root, CDCs are not a new initiative; they are a locally rooted response to a desire to amplify the geographical coverage of sub-city Urban Regeneration Companies (established in 1999) to improve effectiveness and efficiency over a wider geographical area. In other words, the UK government looked at what was going on organically in a number of cities, captured the concept of CDCs from international evidence of what appeared to work in successful metropolitan areas, and then branded it as part of their formative city-region agenda. Indeed, what is more noticeable is how the metamorphosis of sub-city URCs into city-regional CDCs has in fact not taken place - most CDCs are city-wide, while one covers two cities, one is polycentric, and ironically, a number 
are not based on cities at all. As a result CDCs were rebranded as Economic Development Companies in 2007.

Announced at the same time as CDCs, the fourth model of city-region governance focuses on establishing Multi-Area Agreements - a framework through which adjoining local authorities work in partnership to facilitate greater cross-boundary collaboration on economic development issues. To incentivise MAAs the government committed to action to devolve more power and reduce barriers to delivering better outcomes in return for groups of local authorities who set out a convincing case for how they can boost economic growth and tackle deprivation and financial inequalities together across a functional economic area - in other words, a city-region. In contrast to CDCs there has been more appetite for establishing city-regional MAAs, but like CDCs they also exhibit incredible spatial and scalar flexibility - the 15 MAAs established to date cover populations ranging from 330,000 people ( $<5 \%$ of the region) through to 2.76 million ( $>50 \%$ of the region), and areas from $384 \mathrm{~km}^{2}$ to $5,716 \mathrm{~km}^{2}$. And finally, fifth, the latest in what is already a long line of models for cityregional governance is seeing Leeds and Manchester established as the first city-regions outside London to receive statutory powers.

So what does this tell us? It illustrates how, despite the rhetoric used to justify their existence, many models of city-regional governance are not city-regional per se (Harrison, 2009). In part this is enabled by the lack of a workable definition for city-regions, but more broadly, it is symptomatic of a wider trend where much of what is branded as 'city-regional' bears little resemblance to what Scott and others were imagining when conceptualising the global city-region and global city-region governance a decade ago. What we have seen over the past ten years then is the city-region, as the in vogue spatial scale, promoted as 
necessarily contingent to accessing global circuits of capital; a process which both encourages and forces those areas who might at first appear marginal to the city-region agenda to be seen to be politically engaged and attempting to keep up with the major cities and city-regions. What remains as an open question is whether the city-region concept is doing significant work for those places and/or initiatives which have forged links to it by identifying as a city-region or attaching the city-region label?ii

in many cases 'new' agencies actually represent a 'scalar amplification or contraction' of previous entities (LORD, 2009); and (ii) 'new' governance arrangements often 'sit alongside' rather than replace extant institutional frameworks and supports (HARRISON, 2010).

\section{Conclusion}

This chapter set out to explore global city-region governance, ten years on from Scott's (2001a) identification of global city-regions as the pivotal social formation in contemporary globalization. It started from a recognition that, as an analytical concept, the global cityregion is relatively straightforward to define and make different from other concepts. However, it has been argued that in policy and governance terms this task is much more difficult because it has become increasingly tempting to overlook the reality whereby: (i) in many cases 'new' city-region governance frameworks actually represent a 'scalar amplification or contraction' of previous entities (LORD, 2009); and (ii) 'new' governance arrangements often 'sit alongside' rather than replace extant institutional frameworks and supports (HARRISON, 2009; 2010). Often reliant upon outdated and inadequate institutional 
structures, frameworks and supports, to go back to Scott's question of what main governance tasks do global city-regions face as they seek to preserve and enhance their wealth and well-being, this chapter emphasises the need to understand how city-regions are constructed politically. For when it comes to governance and the rescaling of state power, in this case to city-regions as the in vogue spatial scale, there is no blank piece of paper upon which new governance arrangements can be established. Rather, as evidenced by attempts to build a tier of city-region governance in England, new rescaling strategies collide with, are constrained by, and can only partially rework inherited landscapes of state scalar organisation (Brenner, 2009). In other words, the major challenge going forward lies in developing more concrete examples of the barriers to institutional reorganisation and how extant institutions working at or across multiple scales enable and constrain processes of state rescaling: a view that would seem to lend support to Allmendinger and Haughton's $(2009$, p.626) contention that in future work:

"... it is important to examine how rescaling works across multiple scales ... rather than simply privileging specific scales of governance. It is how the many scales of governance intersect and interact which matters, not simply the scales which are perceived to be the primary 'beneficiaries' or 'losers' in rescaling".

\section{References}

Allmendinger, P. and Haughton, G. (2009) 'Soft spaces, fuzzy boundaries, and metagovernance: the new spatial planning in the Thames Gateway', Environment and Planning A 41, 617-633.

Brenner, N. (2009) 'Open questions on state rescaling', Cambridge Journal of Regions, Economy and Society 2, 123-139. 
Cheshire, P. and Magrini, S. (2009) 'Urban growth drivers in a Europe of sticky people and implicit boundaries', Journal of Economic Geography 9, 85-115.

Christaller, W. (1933) Die Zentralen Orte in Süddeutschland, Gustav Fischer, Jena.

DCLG (2008) Review of Economic Assessment and Strategy Activity at the Local and Subregional Level. Department of Communities and Local Government, London.

Hall, P. (2001) 'Global cities and global city-regions: a comparison', in A. Scott (ed) Global City-Regions: Trends, Theory, Policy, Oxford: Oxford University Press, pp. 59-77.

Harding, A. (2007) 'Taking city regions seriously? Response to debate on 'city-regions: New geographies of governance, democracy and social reproduction', International Journal of Urban and Regional Research 31, 443-458.

Harrison, J. (2007) 'From competitive regions to competitive city-regions: a new orthodoxy, but some old mistakes', Journal of Economic Geography 7, 311-332.

Harrison, J. (2009) 'Life after regions? The evolution of city-regionalism in England', GaWC Research Bulletin 326 http://www.lboro.ac.uk/gawc/rb/rb326.html

Harrison, J. (2010) 'Networks of connectivity, uneven development, territorial fragmentation: the new politics of city-regionalism', Political Geography 29, 17-27.

Hudson, R. (2007) 'Regions and regional uneven development forever? Some reflective comments upon theory and practice', Regional Studies 41, 1149-1160.

Jonas, A. and Ward, K. (2007) 'An introduction to a debate on city-regions: new geographies of governance, democracy and social reproduction', International Journal of Urban and Regional Research 31, 169-178. 
Lord, A. (2009) 'Mind the gap. The theory and practice of state rescaling: institutional morphology and the 'new' city-regionalism', Space \& Polity 13, 77-92.

Lovering, J. (1999) 'Theory led by policy: the inadequacies of the new regionalism (illustrated from the case of Wales)', International Journal of Urban and Regional Research 23, 379-395.

Office of the Deputy Prime Minister (2005) Planning Glossary, London: ODPM.

Parr, J. (2005) 'Perspectives on the city-region', Regional Studies, 39, 555-66.

Scott, A. (ed) (2001a) Global City-Regions: Trends, Theory, Policy, Oxford: Oxford University Press.

Scott, A. (2001b) 'Globalization and the rise of city-regions', European Planning Studies, 9, 813-826.

Scott, A., Agnew, J., Soja, E. and Storper, M. (2001) 'Global city-regions', in A. Scott (ed) Global City-Regions: Trends, Theory, Policy, Oxford: Oxford University Press, pp. 1130.

Tewdwr-Jones, M. and McNeill, D. (2000) 'The politics of city-region planning and governance', European Urban and Regional Studies, 7, 119-134.

Thrift, N. (2002) 'Performing cultures in the new economy', in Du Gay, P. and Pryke, M. (eds) Cultural Economy, London: Sage, pp. 201-234.

UNFPA (2007) State of the World Population, New York: UNFPA.

\footnotetext{
'A notable exception to this rule is Shanghai, where the city and city-region population are equivalent at 18.2 million and, therefore, the governance arrangements cover the larger metropolitan area.
} 


\footnotetext{
ii $A$ similar trend has been identified in academic circles, with the concept of the city-region now increasingly used by authors as a vehicle to push their own particular (often unconnected) agenda, rather than doing significant work (Harding, 2007).
} 